XIV. Description of a new Genus of Coleopterous Insects inhabiting the Interior of Ants' Nests, in Brazil. By J. O. Westwood, F. L. S., \&c.

[Read 7th August, 1854.]

ThE recent discovery of numerous remarkable species of Coleopterous insects in the interior of ants' nests, amongst the former of which are to be included many species of the family Paussidee, and the not less singular discovery of several most anomalous species of Staphylinida in the nests of white ants, in Brazil, have induced our indefatigable correspondent in Brazil, Mr. W. H. Bates, to search the nests of these different insects, in the hopes of meeting with new species of Paussida, or other equally curious insects in such situations; nor has his search been entirely fruitless, since, although he has not detected any member of the family Paussidae (one of which had, however, been found on the Corcavado mountain, near Rio Janeiro, by Mr. Miers), he has been fortunate enough to capture several specimens of a small Coleopterous insect, of an entirely new type, whose situation in the order is very uncertain, and whose structure is, in many respects, as remarkable as that of any known insect of the Coleopterous order.

Having been allowed to examine these interesting insects in detail, I am enabled to lay before the Society figures and descriptions of all those important organs, upon the variations of which the distribution of the order Coleoptera has been established; especially the structure of the antennæ, trophi, tarsi, veining of the wings, and the number of the segments of the abdomen.

It is especially worthy of notice, that, whilst many of the species of beetles found in ants' nests are destitute of organs of sight, the eyes exist in the insect under consideration, of the ordinary size and structure.

The following are the characters of the genus which I propose for the reception of the insect in question.

\title{
Gnostus, Westw.
}

Corpus minutum convexum, rigidum, politum, capite parvo, elytris magnis oblongis, postice rotundatis, abdomen omnino tegentibus. Caput minutum, in cavitate antica prothoracis fere ad oculos immersum, antice rotundato-subporrectum, pone oculos utrinque profunde et oblique impressum. Oculi 
sat magni laterales transverso-ovales. Antennce paullo ante angulos internos oculorum insertæ, pronoto breviores subcylindricæ; articulo 1 mo subclavato, curvato, apice oblique truncato, articulo 2ndo in angulum inferum truncaturæ apicalis articuli basalis inserto, basi gracili supra in angulum subacutum producto, articulo 3tio elongato, cylindrico apice truncato, subtus fere ad medium in angulum obtusum producto; hoc articulo, certo situ, quasi ex articulis sex arctissime conjunctis apparenti. Os minutum, instrumentis cibariis haud porrectis. Labrum parvum, transversum, antice angulato-productum. Mandibula parvæ, corneæ, subtrigonæ, dente minuto acuto apicali armatæ. Maxill $\propto$ minutæ, basi extus corneo, lobo unico apicali gracili intus setoso instructæ; lobo ad basin quasi articulato. Palpi maxillares, ut videtur, tantum 3 -articulati (articulo ordinario basali forsan obliterato vel subobsoleto) : articulo 1 mo basi curvato, apice parum crassiori; articulo 2ndo brevissimo annuliformi; 3tio majori, in medio parum ovali-inflato, apice acuto, setis nonnullis brevibus instructo. Mentum corneum, transverso-quadratum, angulis anticis lateralibus parum porrectis et obtusis, spatio intermedio valde depresso. Labium transversum, in medio inter palpos subconice productum et setosum. Palpi labiales minuti, 3-articulati; articulo 1 mo minimo annuliformi, 2ndo curvato sensim attenuato, 3tio ovali, apice subacuto, setisque nonnullis instructo. Prothorax oblongus, quasi in duas partes valde inæquales (postica multo minori) impressione divisus, pars antica capite multo latior; fossulis duobus paullo curvatis, longitudinalibus in discum notatus, lateribus rotundatis, in parte constricta utrinque in hamos duos apicibus acutis fere conjunctis productis; parte postica transversa fere anticæ latitudine æquali. Scutellum parte detecta parva subcordata punctata. Elytra magna, pronoto fere duplo latiora, antice subtruncata, angulis humeralibus fere rectis, lateribus subparallelis, apice rotundatis; convexa, glabra, parum setosa, punctato-striata, punctis ante apicem desinentibus, callo nullo subapicali. Alæ magnæ, punctis minimis obsitæ, margine ciliato: venis duabus subcostalibus ante medium alæ in stigma mediocre submarginale desinentibus; vena altera infera ante marginem posticum recurva, venula ad marginem emittente alteraque furcata fere obsoleta subanali, dimidio apicali alarum veniś destituto. Pedes breves, femoribus subclavatis, tibiis compressis parum curvatis, externe breviter serratis, apice suboblique truncatis ; tarsis brevibus, omnibus 
simplicibus, 5-articulatis, articulo 5to paullo longiori et graciliori : unguibus simplicibus. Mesosternum brevissimum, metasternum transversum, coxis posticis parvis subrotundatis. Abdomen, ut videtur, 3-articulatum, segmento 1 mo maximo, 2ndo brevissimo, 3tio mediocri subtriangulari.

Species unica. Gnoslus formicicola, Westw. (Pl. VIII. fig. 1.)

$G$. omnino rufo-castaneus, nitidus, corpore et pronoto glabris; elytris punctato-striatis, corpore infra polito impunctato convexo.

Long corp. lin. $1,=\frac{1}{12}$ unc.

Habitat in Brasilia, apud Santarem, in nidis Myrmica (Crematogastris) victimœ, Smith. D. Bates. In Mus. Britann., \&c.

Mr. Bates, supposing the insect (from its antennæ) to belong to the Paussida, thus mentions the capture of this parasite,

"No 140. Myrmica (Crematogaster), neuter and fem., with its formicarium formed in hollow, dried suspended sipós. Only one female in each formicarium. This ant has a small species of Pausside almost invariably in its company, one, or at most two, in each colony. No Paussus was found in any part of the sipó not inhabited by the Myrmica."

In our present dearth of knowledge upon the point we can only speculate upon the object of the residence of this and numerous other small Coleoptera in the nests of ants. That it is not without the concurrence of the latter seems evident, not only from the facility with which a colony of ants would dislodge the intruders, but also from the fact that the ants have actually been seen carrying some of these species of beetles-as, for instance, a species of Paussus - in their jaws. Whether, like the Aphides, these beetles emit peculiar secretions, to which the ants are partial, I am unable to state; but certainly many of the ant-nest beetles are provided with small bundles of curved rigid setæ on various parts of their bodies, of which the uses are unknown, such as the tufts on the heads of the Claviger, and on the pronotum of the Paussida, and in the Gnostus, on the under side of the middle of the third joint of the antennæ. Whether, also, on the other hand, these beetles feed either on the eggs, larvæ or pupæ of the ants, or upon their stores of food, is also conjectural.

Mr. Bates, it will be seen, considers the insect above described to belong to the Paussida; but, except in the paucity of joints in the antennæ, the constricted prothorax, and the short legs with five-jointed tarsi, no actual relation can be traced with that family; 
the structure of the mouth and wings, and the large convex elytra entirely covering the abdomen (closely resembling the genus Lema in this respect), entirely removing it from Paussi. With Claviger, also (to which it bears some slight relation in the structure of its few-jointed antennæ, truncated at the tip), it possesses still less affinity. Its nearest allies, on the other hand, appear to me to be found amongst some of those Xylophaga of Latreille which possess five-jointed tarsi, but with none of these groups does it bear a very close relationship, even if we regard the antennæ as an anomalous aberration.* Ditoma, Colobicus, Synchita, Cicones, Aulonium, Colydium, Teredus, and one or two allied genera, are at once separated from it by their four-jointed tarsi, and by the leathery patch on the lower margin of the wing beyond the middle, and by the veinless apical portion scarcely occupying more than one-third of the length of the wing. Cerylon, also, in its four-jointed tarsi and subulate palpi, is removed from Gnostus. Anommatus, also, which has a glossy castaneo-rufous body, and is a terrestrial insect, has bilobed maxillæ, four-jointed tarsi, \&c. Some of the Cucujide have, it is true, five-jointed tarsi, and the apical veinless portion of the wing is of very great extent, but their maxillæ are bilobed, and the palpi of ordinary form. With Latridius and Holoparomecus, as well as with the minute insects belonging to the Corylophida, $\uparrow$ there appears to be some slight relation in the comparative want of development of the maxillary appendages, but the struc-

* In addition to the great number of species of Brachelytra found in ants' nests, the following genera of the Xylophaga of Latreille have also been found to possess Formicicolous habits :-

Cholovocera formicaria, Motschoulsky, Bull. Mosc. 1838, 177; Markel, Zeitsch. für Ent. v. 255.

Latridius formicetorum and fusculus, Mannerheim, Bull. Mosc. 1843.

Latridius elongatus, Markel, Zeitsch. für Ent. v. 253.

Hypocoprus formicetorum, Motschoulsky, Bull. Mosc. 1839, 72.

Cryptophagus glaber, Gyllenhal, Markel, Zeitsch. für Ent. iii. 218.

Cryptophagus (4 species), Markel, Zeitsch. für Ent. v. 244.

Trichopteryx (1 species), Markel, id.

Corticaria (4 species), Markel, id. 252.

Synchita Juglandis, Markel, l. c.

Ceryion (2 species), Markel, l. c.

Rhizophagus (2 species), Markel, l. c.

Monotoma angusticolle and conicolle, Aubé, Ann. Soc. Ent. France, vi.

Myrmechixenus subterraneus, Chevrolat, Rev. Silberm. iii. 263, and Markel, o. c. v. 253 . As well as

Scydmanus (9 species), Markel, o. c. v. 242; and several species of minute Histerida.

+ Details of several of these genera will be found in the lower part of the 10th plate in Mr. Wollaston's Insecta Maderensia. 
ture of the tarsi, antennæ, \&c. remove them from the genus above described. From the preceding details it will, I think, be evident, that, whilst Gnostus is most nearly allied to such of the Xylophaga of Latreille as possess five-jointed tarsi, it stands sufficiently detached from the whole of them as to constitute a distinct sub-family of its own.

\section{EXPLANATION OF PLATE VIII.}

Fig. 1. Gnostus formicicola, greatly magnified.

Fig. 2. Head seen from above.

Fig. 3. Head seen sideways.

Fig. 4. Antenna seen from behind.

Fig. 5. Labrum.

Figs. 6, 7. Mandibles.

Fig. 8. Maxilla.

Figs. 9,10. Mentum in different points of view.

Fig. 11. Labium and labial palpi.

Fig. 12. Prothorax seen obliquely from the side.

Figs. 13, 14. The lateral hooked portion in different points of view.

Fig. 15. Scutellum,

Fig. 16. Wing.

Fig. 17. Fore leg.

Fig. 18. Fore tarsus.

Fig. 19. Middle leg.

Fig. 20. Hind leg.

Fig. 21. Meso and metathorax, abdomen and hind leg, from beneath. 


\section{$2 \mathrm{BHL}$ Biodiversity Heritage Library}

Westwood, J. O. 1855. "XIV. Description of a new Genus of Coleopterous Insects inhabiting the Interior of Ants' Nests, in Brazil." Transactions of the Entomological Society of London 8, 90-94.

https://doi.org/10.1111/j.1365-2311.1855.tb02665.x.

View This Item Online: $\underline{\text { https://www.biodiversitylibrary.org/item/96544 }}$

DOI: https://doi.org/10.1111/j.1365-2311.1855.tb02665.x

Permalink: https://www.biodiversitylibrary.org/partpdf/69406

\section{Holding Institution}

Smithsonian Libraries

\section{Sponsored by}

Smithsonian

\section{Copyright \& Reuse}

Copyright Status: Public domain. The BHL considers that this work is no longer under copyright protection.

This document was created from content at the Biodiversity Heritage Library, the world's largest open access digital library for biodiversity literature and archives. Visit BHL at https://www.biodiversitylibrary.org. 